\title{
Searching for shalom: Transformation in the mission of God and the Bible translation movement
}

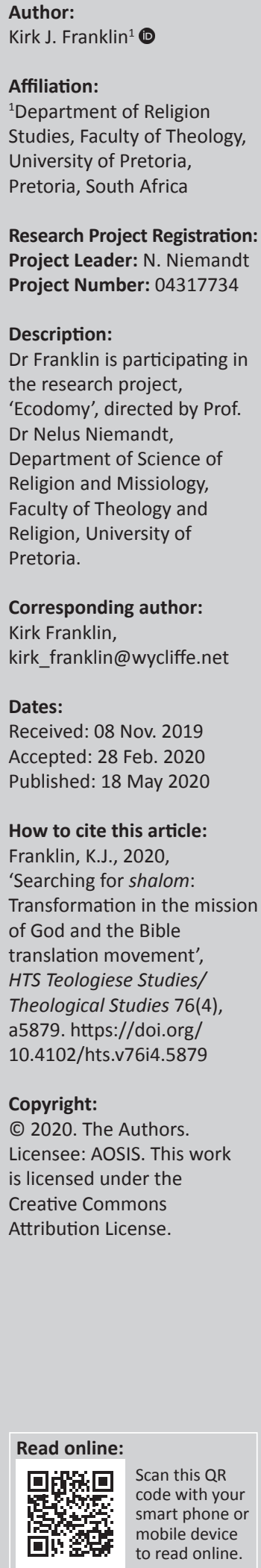

The background of this study was to explore the Old Testament vision of shalom and determine how it was relevant to its holistic mission, Bible translation, transformational development and the world's challenges and trends. The aim of this research was to create a framework to serve practitioners and theorists associated with the Bible translation movement and its intersection with transformational development. The setting for the study was the consideration of factors affecting Bible translation and transformational development in the context of global challenges and trends. The methodology of the study included literature surveys integrated with analysis of data from global sources. Results from the study included an understanding of the relevance of shalom, and integration with holistic mission, including integral mission, and intersection with transformational development. Analysis of global challenges and trends was combined with an existing framework for transformational development that included Bible translation as a mission. The conclusion was that the church was called to be faithful stewards of knowledge and resources. This included an understanding of the relevance of the vision for shalom, integrated with holistic mission, transformational development and Bible translation that addressed in full or in part global challenges and trends that resulted in the framework produced by this study.

Keywords: shalom; holistic/integral mission; transformational development; global challenges; Bible translation.

\section{Introduction}

The aim of this article is to answer this question: what happens when one integrates an Old Testament perspective of shalom, Bible translation and holistic mission with transformational development in response to global challenges? This study is explored through the intentional integration of four objectives: (1) missional implications of the Old Testament vision for shalom, (2) the relevance of holistic mission for transformational development, (3) global trends and challenges (GTCs) and (4) the translation and availability of the Bible as a basis for transformational development.

The manner in which this research is conducted is as follows: the implications for shalom are explored through a literature survey of Old Testament, New Testament, theological and missiological perspectives. The relevance of holistic mission is reviewed through a brief literature survey. The identification of GTCs is provided through an analysis of global experts. The integration of Bible translation and holistic mission is explored using an existing framework for transformational development while also adding references to the global challenges and trends, and hints of shalom. The result is a framework for the church and participants of the Bible translation movement that considers how to have an integral impact on all aspects of society.

\section{An overview of shalom}

The foundational understanding of the Old Testament vision of shalom is essential to the development of the framework. A literature survey is now used to explore this concept.

\section{In the Old Testament}

Shalom is a critical concept in the Hebrew Old Testament appearing 397 times. In modern English translations such as the NIV, there are 113 places where shalom is translated as 'peace' (Goodrick \& Kohlenberger 1999:1500). The examples are given in the following.

God promised the Israelites a harmonious state between themselves, their enemies and even wild animals around them (Lv 26 NIV): 
I will grant peace in the land, and you will lie down and no one will make you afraid. I will remove wild beasts from the land, and the sword will not pass through your country. (p. 6)

The condition for peace was obedience to God's commands and avoidance of idol-making activity.

Gideon declared shalom as an attribute of God: 'So Gideon built an altar to the Lord there and called it The Lord Is Peace' (Jdg 6:24, NIV). The context was that Gideon assumed he would die after seeing the angel of the Lord. However, that was not going to be the case. In response, Gideon stated that shalom as part of God's nature and God gave his peace to whatever context and people he chose.

The psalmist David described shalom as God's exaltation upon his people: 'The Lord gives strength to his people; the Lord blesses his people with peace' (Ps 29:11, NIV). The blessing of peace came from God.

Another example was when Israel reclaimed land from its enemies: 'The towns from Ekronto Gath that the Philistines had captured from Israel were restored to Israel ... And there was peace between Israel and the Amorites' (1 Sm 7:14, NIV). After gaining the territory, Israel and the Amorites entered into a season of shalom - of peaceful co-existence.

Richard Foster (2005:loc 531) notes how the prophet Isaiah foretold an instance of reconciliation, justice and righteousness, 'a time when the wholeness of God's peace would rule and people would "walk in the light of the Lord" (Is 2:4)'. God says in Isaiah, 'I will make peace your leader and righteousness your ruler' (60:17b, NLT). Shalom does not exist where sin and evil are tolerated: 'if only you had paid attention to my commands, your peace would have been like a river, your well-being like the waves of the sea' (Is 48:18, NIV).

When the prophets spoke about shalom, they envisioned a time when people no longer fled from God and instead readily entered into harmonious relationships with God and gathered with 'true delight' (Wolterstorff 1983:72) at 'the mountain of the Lord' (Is 2:3). David Burnett (1986:72) describes how for the Israelites, 'the shalom culture' of justice and freedom for the whole person 'was to be a witness to the nations drawing them [e.g. in a centripetal way] to God'. Foster (2005:loc 515) calls this 'the dream of shalom' when the nations would gather at the temple of God to learn from him and walk with him.

Other ways shalom is translated into English are determined by context. Words and phrases in the NIV include the following: 'safety, prosperity, well-being; intactness, wholeness; peace can have a focus of security, safety which can bring feelings of satisfaction, well-being and contentment' (Goodrick \& Kohlenberger 1999:1544).

In summary, in the Old Testament, there is a diversity of meaning of shalom: it is about 'a physical state of well-being, to things being as they ought to be in the material world' (Yoder
1997:13), it is peace as a way of living, a blessing from God, an attribute of God that reflects his character of righteousness, love, justice, peace and perfection, and it is a state of being from God.

\section{New Testament equivalent}

The Greek eirene is similar in concept to shalom and is translated as 'peace, harmony, tranquillity, safety, welfare, health, often with an emphasis on lack of strife or reconciliation in a relation, as when one has "peace with God"' (Goodrick \& Kohlenberger 1999:1544). One example is how the apostle Paul uses eirene in the context of the outcome of the redemptive work of Christ: 'since we have been justified through faith, we have peace with God through our Lord Jesus Christ' (Rm 5:1, NIV). An individual experiences peace through the hope of salvation from a new relationship with God.

James Davison Hunter (2010:228) states that the entire biblical narrative centers around the shalom God intended and that he will, one day, restore'. Christ entered our history to 'model shalom' (Hunter 2010:229) through his redemptive work, compassion and miracles. In other words, as the apostle Paul stated, 'For he is our peace, the one who made both groups into one and who destroyed the middle wall of partition' (Eph 2:14, NET).

Christ came to be our shalom and to inspire a 'lived-vision of the shalom of God within every place and every sphere where Christians are present' (Hunter 2010:248).

When Jesus said he came 'that they may have life, and have it to the full' (Jn 10:10, NIV), Bryant Myers (1999:51) notes how this fullness of life is 'present in relationships that are just, harmonious, enjoyable, that allow everyone to contribute. And to live fully for all time'.

\section{Comprehensive relationships}

Richard Foster (2005:loc 510) observes how shalom is 'a fullbodied concept that resonates with wholeness, unity [and] balance'. An outcome is an end to violence because change is brought about through 'reconciliation of parties formerly in conflict' (Kirk 2006:125). Shalom is optimistic about relationships because it sees 'an authentic and nurturing community' (Myers 1999:51). Peoples of all nations share equally in God's loving concern because he is above favouritism and shows none to anyone - no person, people group, language or nation is above the other in God's eyes.

The reign of God leads to peace and justice - to God's shalom community where people dwell in peace and enjoy living 'with God, with self, with [others and] with nature' (Wolterstorff 1983:69). It is a holistic peace that influences all manner of relationships because they are harmonious and mutually edifying. It is where all participants fully develop their human potential because they are secure, cared for, flourishing and mutually respectful. This community is filled 
with God's blessing and is a place that is free from ungodly behaviour.

There is total harmony within the community because 'the Lord blesses his people with peace' (Ps 29:11b, NIV).

\section{Spiritual and socio-economic blessing}

A community may be living in peace with its neighbours and 'yet be miserable in its poverty' (Wolterstorff 1983:69). Importantly, shalom therefore includes the idea of physical well-being in the form of 'physical security, emotional health and material sustenance' (Woodford 2007:47). It is noticed through the 'absence of physical threats like war, disease and famine' (Yoder 1997:13).

The material blessing includes the unrelenting presence of God that affects one's 'spiritual well-being' (Harris 1970:27). Shalom also involves 'economic well-being and socio-political stability' (Sultan 2007:23). The vision of shalom has socio-economic influence because it is 'the theology of enough' where greed is alleviated when the poor who 'are no longer oppressed, because covetousness no longer rules' (Foster 2005:loc 525).

\section{A reign of peace}

Definitions of 'peace' include the idea of 'mutual harmony between people or groups, public order and security, freedom from strife or dissension [or] tranquility or serenity, ... silence or stillness' (Dictionary.com).

Andrew Kirk (2006:125) notes that such meanings give 'a sense of the absence of conflict and strife' because peace can mean the lack of something - a generally negative connotation. Perry Yoder (1997:13) elaborates: peace is the absence of something: turmoil, distress, or war; rather than the positive presence of things as they should be'. Those who want to make peace could be seen as passive or avoiding struggle. While, in Hebrew, shalom is fuller because it brings 'physical well-being' (Yoder 1997:13, 15), 'the presence of positive and good relations as marked by justice' and 'just and health giving relationships between people and nations'.

Shalom is fulfilled when the kingdom of God is established over all creation. It is the time when shalom and righteousness reign forever. The sons of Korah poetically painted a picture of what 'God's plan' (Ott 2004:10) would look like: 'he will make peace with his people, his faithful followers ... Certainly his loyal followers will soon experience his deliverance; then his splendor will again appear in our land' (Ps 85:8-9, NET).

Bernhard Ott (2004:10) refers to this as 'God's shalom project [because] God wills peace'.

\section{The missio Dei and shalom}

Georg Vicedom, who popularised the concept of the missio Dei in 1961, positioned the mission of God with 'the Kingdom of God and the establishment of shalom in the world'
(Hesselgrave 2016:loc 5090). Shalom is embedded in the kingdom of God as an outcome of the mission of God because its overall aim is to 'establish shalom' (Engelsviken 2003:489) as the reign of God through 'peace, integrity, community, harmony and justice' (McIntosh 2000:632). As Nicholas Wolterstorff (1983:72) states, 'We are workers in God's cause, his peace-workers'.

\section{Shalom and Bible translation}

The Bible agency Wycliffe Global Alliance (WGA 2019:2) speaks to Bible translation programmes needing to be shaped and guided by 'transformational impact' as a vision for shalom in 'transformed communities [because] God uses the translated Word as a foundational means for holistic transformation'.

Sarah Starrenburg (2019:n.p.) of United Bible Societies notes a justice element of shalom in how Bible translation (1) 'promotes equality of access' because power is not to be a determining factor of who has access to the Bible; (2) 'enables agency' because people do not need an intermediator to explore the scriptures concerning the 'most important matters shaping ... life and beliefs'; (3) 'affirms identity', using Genesis 1:26, for example, in the Inuktitut language spoken by the Inuit people in Canada is to say, 'let us make Inuit in our image'. This is a 'powerful affirmation of cultural identity [as] image bearers of God'; (4) 'preserves cultures that are in danger of being suppressed by more culturally dominant language groups'; and (5) enables a community to theologise by brining 'their own unique cultural perspectives to bear'.

\section{Summary}

The use of shalom in the Old Testament is wide-ranging because it refers to wholeness, well-being, abundant life, satisfactory conditions, completeness, soundness, peace, wellbeing and salvation. It describes the way the world ought to be - the vision of an integrated whole of all manner of relationships. It implies a state of mind that is at peace and is satisfied and nothing is lacking. People and their communities are characterised in their relationships with each other, God and creation as being just, peaceful, harmonious and enjoyable. It envisions a new community that breaks down the barriers of language, economy, race, gender and nationalism.

It is a transformed community that is called to make peace, seek justice, provide for all who are in need and protect the exploited and the oppressed.

This Old Testament vision of shalom provides a theological and missiological foundation for the framework under development. Next is the consideration of holistic mission and transformational development because they assume elements of shalom.

\section{Defining holistic mission}

Holistic Christian mission is quite well defined. Consider, for example, the Lausanne Committee for World Evangelization's 
Occasional Paper No. 33, which deals in its entirety with the subject. In that paper, Rene Padilla (2004:11) states that the mission of God is holistic because it is (1) evangelism understood as 'the proclamation of the historical, biblical Christ as Saviour and Lord, and with a view to persuading people to come to him personally and be reconciled to God'; and (2) associated with 'social transformation resulting from God's action in history through human agency'. Holistic mission has 'no biblical dichotomy between the Word spoken and the Word made flesh in the lives of God's people' (ed. Douglas 1975:1294). Holistic mission is all encompassing because it is 'what the church is, what the church does, and what the church says' (Padilla 2004:13).

\section{Integral and holistic mission}

The concepts of holistic mission and integral mission are interchangeable. For example, holistic mission is to follow 'Christ's example of service to the whole person' that recognises the physical, spiritual and emotional needs of all people (Van Wynen, Crough \& Franklin 2019:3). Micah Global (n.d.:n.p.) defines integral mission as the 'proclamation and demonstration of God's love'. Padilla (2004:14) states it as the 'proclamation and demonstration of the gospel'. The word 'integral' recognises a wide diversity of ministry that needs to be integrated in order for there to be 'holistic ministry that glorifies God and shares the truth and love of God with all peoples' (Van Wynen et al. 2019:3).

In essence, holistic or integral mission is the complete counsel of God transforming the whole person and the person's entire context. It is the deliberate 'process of facilitating change' throughout an entire community (Voorhies 1999:588). It intentionally integrates the role and influence of the church in the transformation of society. This change aims to see the whole person becomes like Christ in all areas of life: the 'material, social and spiritual - as well as in the community - economics, social and political' (Winter, Steven \& Hawthorne 1999:588).

A considerable focus of holistic mission is transformational development. Bryan Myers (1999:3) defines this as 'seeking positive change in the whole of human life materially, socially, and spiritually'. It is a journey that never ends and its intention is to regain one's 'true identity as human beings created in the image of God' and to discern one's calling as 'productive stewards, faithfully caring for the world and all the people in it' (Myers 1999:3).

\section{Holistic mission and Bible translation}

Holistic mission is not focussed on a set of particular priorities but is more concerned about the 'parts of a whole' (Steward 2000:448). In the context of Bible translation, the focus needs to shift from what still needs to be performed (i.e. the number of languages that are yet to be translated) to how Bible translation integrates into and serves God's holistic and transformational plan for the nations.
Of particular concern for Bible translation is linguistic minorities - people and their communities that are on the margins of society. Bruce Bradshaw (2000:966) states that what is at stake for these communities is their 'survival strategy in a particular culture' that involves the comprehensive 'combination of agricultural, medical, religious, educational, commercial, construction, and household activities that contribute to human welfare'.

\section{Summary}

Holistic or integral mission involves the demonstration and proclamation of God's love. It recognises a diversity and range of ministry expressions that glorify God. It focuses on God's transformational plan for peoples of all nations. It intersects with the Old Testament vision of shalom because both share a concern about wholeness, completeness, wellbeing and salvation of all people and relationships.

Holistic or integral mission adds to a theological and missiological foundation for the framework under development. Next is the identification of GTCs that need to be considered in order for transformational development to occur.

\section{Global challenges and trends facing transformational development}

Brian McLaren (2007:46-49) identifies global problems through exploration of the Copenhagen Consensus, the World Bank, Saddleback Church's P.E.A.C.E. Plan and the Millennium Development Goals. We have integrated McLaren's work with that from First Fruit Inc., a Christian philanthropic foundation released the Global Trend Analysis produced 'through the counsel of various Christian thinkers from around the globe' (First Fruits 2009a:n.p.). The report outlined 10 'Global Trends' and five 'Undercurrents that Underlie all Trends' (First Fruits 2009b:n.p.). A 'global participatory think tank' called The Millennium Project (2009a:n.p., 2009b:n.p.) out of the United Nations University produced '15 Global Challenges [that are] a framework to assess the global and local prospects for humanity'. In 2015, the eight Millennium Development Goals were updated by the United Nations to become 17 sustainable development goals. All of this data were analysed to ascertain similarities and differences in these sources. This was grouped and summarised into the following 10 statements of GTCs:

1. Christian faith: The church finds new homes across the globe as it moves from the West or North to the South or East and indigenous movements, and even back again. It is committed to the proclamation of the gospel as the solution to spiritual hunger while simultaneously addressing social justice issues. The church addresses nominalism and disenchantment with institutional forms of the church. It uses dialogue and peacemaking initiatives with followers of other religions as it upholds values of a just and respectful society.

2. Education and development: The people of the world are literate and illiterate with some preferring to remain as oral 
learning communities. Others are deaf or hearing impaired and actively use sign languages. All people are given the right tolearn and develop themselves and their communities. Learning is a lifelong journey and education intends to increase intelligence, knowledge and wisdom in an ethical manner that creates responsible citizens who use their learning to develop solutions that address global challenges.

3. Women and children: The socio-economic exploitation of women and children because of poverty, conflict and other forms of injustice is addressed globally. Situations are improved because empowerment, especially of women and children, is essential for addressing the challenges facing humanity and improving the human condition in general.

4. Water and food: Sustainable clean drinking water is a basic human necessity and ensuring that it is available along with basic sanitation that is addressed without exacerbating local, regional and global conflicts. This helps alleviate hunger, brings about food security, improves nutrition and promotes sustainable agriculture while also tackling rampant population growth that places pressure on sustainable agriculture and food production.

5. Improved health: Infant-child mortality is greatly reduced globally. The health of children and the aged is a priority. Breakthrough solutions are made for the control and treatment of malaria and infectious and re-emerging diseases.

6. Economic opportunities: Extreme poverty in all of its forms is eradicated through sustainable development with increased economic opportunities. Philanthropists channel funding towards such goals. People have employment opportunities and are productive in meaningful work environments free from exploitation. Ethical market economies emerge and the gap between rich and poor is reduced.

7. Environment and energy: Sustainable methodologies deal with the effects of climate change, especially upon the world's poor. Priority is given to improved management of natural resources including the earth's rivers, seas and oceans. Poor air quality is addressed. Forests and other essentials of the world's ecosystems are managed sustainably to reverse land degradation and halt the loss of biodiversity. Affordable, reliable, sustainable and modern energy is accessible for all of humanity.

8. Societal complexities: Civil wars and ethnic conflicts are addressed. Radicalism is reduced through interventions and peacemaking. Transnational organised crime networks are stopped from becoming more powerful and sophisticated. The basic human right of religious freedom is protected and religious persecution is eliminated. Outcomes of mass immigration of people, tribalism and xenophobia, restlessness among youth and other social challenges are addressed. Cities and human settlements are safe, sustainable, resilient and fair to all. Healthy living and well-being for all people of all ages is prioritised.

9. Ethical governance: Transparent and accountable governance that addresses corrupt leadership is the norm. Institutions at all levels become just, fair, accountable, inclusive and promote peaceful environments. Authoritarian regimes are confronted regarding the guarantee of basic human rights. Ethical decision-making considers how humanity needs a global, multifaceted, general long-term view of a brighter future accompanied with long-range goals with improved global foresight.

10. Sensible innovation: Computational science, innovation and engineering produce inclusive and sustainable development that improves the human condition and consumption and production patterns. The Internet provides widespread social platforms and interconnectedness. Governments pay greater attention to security around technology.

In summary, these 10 GTCs have been identified and summarised utilising global sources. These trends and challenges contribute towards a framework for holistic mission, transformational development and the integration of Bible translation as mission (BTM). Taken together, they hint at what a vision for shalom could look like. They benefit from triangulation with other sources. This follows with Voorhies's 10 principles for holistic mission and BTM.

\section{Key findings}

Samuel Voorhies (1999:586-591) provides 10 principles for holistic mission. While Voorhies's work is over 20 years old, Alfred Ngoma speaks to its relevance in his creation of a 'Biblical Framework for Sustainable Development in the Reformed Church in Zambia'. Ngoma integrates Voorhies's principles because they support 'transformative and sustainable development ... in any given community' (Ngoma 2013:95). Voorhies's principles that follow provide the basis of a framework that enables for the integration of the 10 GTCs and BTM.

\section{Valuing people}

1. 'Recognise the value of people: Respect and value people in the context of their local culture'.

Global trends and challenges: Women and children, education and development, Christian faith, economic opportunities, ethical governance and societal complexities.

Bible translation as mission: There are 3350 languages with some form of Scripture (complete Bible, New Testament only or selections and stories) and current estimates are that there are '1,879 spoken languages and 284 sign languages' that likely need some form of Bible translation (WGA 2018:n.p.).

People and their culture have intrinsic value because Bible translation respects and focuses on people's heart language and their identity within their own culture. For example, Bible translation on the African continent ensured that cultural communities were persevered because of infusion 'with a spirit of stimulus and conservation with its linguistic investigations and its adoption of local religious vocabulary to express Christian teaching' (Pitman, Habito \& Muck 1996:341).

Research conducted for Seed Company, discovered (Reesor, Chandler \& Gackenbach 2009): 
[E]ngagement with Scripture in the mother tongue was also evidenced by the recognition that all members of the community have value ... [T] he presence of a mother tongue translation reinforced modification in the role of women in light of Scripture's clearer instruction on the balance appropriate to gender and power relationships. (p. 11)

\section{Respecting local culture}

2. 'Understand and respect local culture. Yet discern that while each person is intrinsically valuable, every culture has both positive and negative aspects that may or may not be compatible with biblical teaching'.

Global trends and challenges: Societal complexities, education and faith, Christian faith and women and children.

Bible translation as mission: Bible translators carefully study and respect the local culture. Lamin Sanneh (2002:99) notes that, 'a culture that for the first time possessed a dictionary and a grammar was... endowed for renewal and empowerment, whether or not it adopted Christianity'. Ray Aldred (2003:n.p.) states that a heart language expresses people's 'spirituality, ... economics, and ... political aspirations'. The commitment to translation in the heart language ensures that God's message to people is 'couched in their own language and culture ... so that God's power and authority come $[s]$ to them directly in their culture' (Shaw 2000:125).

\section{David Harrison (2010) notes how:}

Bible translation is transformative for a language, especially during the life of the project itself, when it engages some of the best minds of the community in solving formidably difficult problems in semantic mapping, orthography, metaphor, and language standardization. (p. viii)

Bible translation contributes to the transformation of local cultures. An example is among the Dega people of Ghana where vernacular scriptures increased their 'low level of self-respect' (Hill 2006:86) and literacy efforts helped open new doors of opportunity by encouraging people to engage with scripture. This is an example of how the message of the Bible impacts culture because "without a theology that is grounded in local realities, the church remains foreign and fragile' (Hill 2006:86).

\section{Believing in human potential}

3. 'Believe in the person's capacity to contribute and determine his/her future. Help people meet their basic needs with dignity and self-respect. No matter how poor, every community and every individual has something to contribute. Identifying and starting with local resources is a key to people's sense of ownership and self-dignity'.

Global trends and challenges: Christian faith, women and children, improved health, water and food, sensible innovation, economic opportunities and education and development.

Bible translation as mission: People's needs and self-respect must be considered in Bible translation programmes to ensure ownership and self-dignity. Successful programmes start with identifying and using local resources as the foundation of a sustainable process. Part of this process is that of grappling with technical areas of designing the alphabet, the writing script, how the language is structured including its grammar and analysis of the culture.

When people in a community have a greater sense of worth and self-identity in contexts of marginalisation, these indicators may be noted (Reesor et al. 2009):

$[H]$ igher literacy rates, greater utility of the mother tongue language ([such as in] signage, government documents, and health pamphlets) [and] the desire to express original and external media in their mother tongue. (p. 7)

In its research in Africa, OneBook (2014:3) noted how effective transformational projects had 'strong literacy programmes to ensure mother tongue literacy' that included 'functional subjects - AIDS, health, better agriculture, math, poverty alleviation, etc.', and literacy programmes led within the local church 'expanded into the community and then into the school system' and 'pastors promoted the importance of literacy'.

\section{People and leadership}

4. 'Make people, rather than technology, the focal point. When local people are involved in making decisions, they ultimately take responsibility for determining their future'.

Global trends and challenges: Sensible innovation, societal complexities and ethical governance.

Bible translation as mission: In Bible translation, people are the focus. It is possible, however, that because of the 'high tech' nature of Bible translation because of the usage of computer technology, there may be some who may find it difficult to keep this balance. For example, Seed Company research notes the importance of quality leadership that have the ability to (Reesor et al. 2009):

$[M]$ anage translation projects, meet organizational objectives, effectively communicate, form partnerships, and network to solve problems within the community beyond the scope of the translation project [that] produces changes in capacity and performance as leaders. (p. 1)

Such leadership manages the translation projects and collaborates within a translation team and its local community. When newer technology arrives, the translation community shows leadership by ensuring that instruction is available in the local language, which, in turn, promotes the assimilation of 'these technologies in culturally appropriate ways as the community begins to understand them as tools for their own use' (Reesor et al. 2009:9).

\section{Impact of poverty}

5. 'Realize that poverty includes physical, material, spiritual and social dimensions. Involve the whole person - mind, body and spirit, in any development effort. Avoid segregating these and design programs that address the whole problem and the whole person'. 
Global trends and challenges: Water and food, improved health, economic opportunities and environment and energy.

Bible translation as mission: Bible translation has historically focussed on the mind - on theological, evangelistic and discipling aspects of the Christian life. The needs of the body and spirit are outcomes of the scriptures being integrated into people's daily lives. In a holistic sense, literacy plays an important partnership in the Bible translation task. This is because people need to 'develop their own literature expressing in writing what has heretofore been available only in oral form' (Shaw 1988:238). Literacy provides minority languages with value and a greater socio-political status through developing a positive environment where these groups have their rightful place in the larger society. A growing literate society supports various social and economic gains for the community.

Research conducted by OneBook among 5500 people in language communities in Burkina Faso and Cameroon concluded that literacy programmes need a wide body of literature relevant to the church and society. It can also be an incentive to have higher numbers of mother tongue students because it contains information responding to a demand within the community' (Konfe-Tiendrebeogo, Ngum Kimbung \& Engeler 2014:16).

William Carey's mission work in India in the 1700s had what turned out to be a fivefold holistic strategy: the understanding of the language, culture and thought process of the nonChristian peoples; the preaching of the gospel by every means possible; the translation of the Bible into the languages where it was needed; the planting of a church as the earliest possible point; and the training of local Christians to be leaders in ministry (Neill 1986:224-225).

Another example is Bartholomew Ziegenbalg who went to southeast India in the 1600s to work with the Tamil people. He believed that the vernacular scriptures needed to be available at the earliest possible stage of mission. His was a broad strategy because he believed that Bible translation had to go hand-in-hand with Christian education. The new Christians and their children had to be able to read the Bible for themselves. He also believed that the diligent study of the philosophy and culture of the people was foundational to evangelism and church growth. He carried out medical work, pursuing the formation of an indigenous church with its own unique ministry. He insisted on the use of Tamil lyrics in worship. He was totally committed to the personal conversion of the Tamil people. Ziegenbalg was considered ahead of his time in his holistic approach (Neill 1986:196).

\section{Word, deed and sign}

6. 'Approach development in a way that seeks to communicate Christ through word - communicating the gospel of Christ; deed - serving as Christ would, bringing healing and exemplifying righteousness; and sign - working with God's help so that Christ's kingdom life is demonstrated'.
Global trends and challenges: Education and development, women and children, water and food, improved health, economic opportunities, environment and energy, ethical governance and sensible innovation.

Bible translation as mission: Bible translation projects have wider leadership influence and acceptance within a community when they include or network with community development approaches that address the holistic needs and concerns of the community.

Lamin Sanneh (2002:99) commenting on the development of the African Independent Church movement notes that during the centuries of upheaval and expansion of the church, missionaries 'became pioneers of linguistic development [with] the resulting literacy, however limited, produced social and cultural transformation'. Research conducted in language communities in Burkina Faso and Cameroon concluded that literacy programmes needed to consider 'the prevailing socio-economic environment, as well as the needs and opportunities within the community' (Konfe-Tiendrebeogo et al. 2014:16).

Bible translation employs disciplines that are holistic: literacy (addressing issues of illiteracy, which can also be linked to poverty and human rights), sociolinguistics (learning how people use language in their social situation, which can affect politics, business and community life), ethnomusicology (understanding and valuing the music of people as an expression of identity), anthropology (appreciating the cultural factors and the identity issues associated with them), linguistics (including language analysis, alphabets, language learning and pedagogical methods and procedures) and translation ('transmission of a message from one language to another whether in written or oral form') (Silzer 2000:967).

The ability to freely use one's vernacular language is a basic human right, regardless of how small the language may be because 'without language, culture and civilization [is] impossible' (Elson 1987:n.p.). Nonetheless, people who prefer to use a minority language face unique challenges. For example, UNESCO notes that forcing children to learn in a language they do not understand gives them an 'educational handicap' (UNESCO 2007:n.p.).

Gina Cantoni (1997:n.p.) states that educators should therefore 'identify the beliefs and attitudes that underlie the marginalization of [people's] languages and cultures'. The purpose is to find ways to help them assimilate into languages of wider communication. According to SIL International, speakers of 'non-dominant' languages are regularly marginalised 'socially, politically, economically and educationally' (SIL n.d.:n.p.).

Catherine Young (2011:165) refers to this as 'ethnolinguistic marginalization'. An example is speakers of the Kenye language of Uganda. They use other languages spoken around them because they are nervous of revealing their 'true identity' for fear 
of encountering discrimination and marginalisation (Ethnologue n.d.:n.p.). Young (2011:161) states that basic educational rights must extend to those who are marginalised such as women and girls, the poor and 'ethnolinguistic minorities'.

Numeracy training provides practical skills to lessen the likelihood of getting cheated in business transactions. It can also provide economic advancement because being able to read and write increases one's ability for personal and economic achievement.

Not all societies are comfortable with reading and writing because they have oral traditions. Therefore, oral strategies of introducing the themes and stories of the Bible have been important for such societies. When this is the lead strategy, Philip Jenkins (2006:31) notes, 'learning to read the text is a later, and not inevitable, phase of Christian development'.

\section{Impact of interventions}

7. 'Realize that all interventions into a group of people (social, technical, economic or educational) carry a message that must be understood and interpreted from the recipient's world view'.

Global trends and challenges: Ethical governance, education and development, economic opportunities, societal complexities and sensible innovation.

Bible translation as mission: The issue of marginalisation is of great concern within God's mission because of the tragic conditions many people face, whether from political instability, rising religious fundamentalism and religious persecution, or socio-economic pressures. These are influenced by the imbalance of wealth and power. Left unaddressed, they create extreme forms of disadvantage and marginalisation. It is no wonder that the global church is increasingly called upon to speak into these issues.

Bible translation and the engagement of vernacular scripture 'influences governance of communities and their interaction within a network of other communities' (Reesor et al. 2009:10). Research conducted in such communities noted that frequently (Reesor et al. 2009):

$[M]$ other tongue translation affects community transactions and examples, such as birth and funeral customs, criminal and judicial practices, political operations, as well as ceremonies and celebrations, were cited in the groups. (p. 10)

\section{Recognising God at work}

8. 'Recognize that God is already at work in the community. Part of the external facilitator's tasks is to discover what God is doing and support what may already be happening as a bridge to how God wants to use the external resource and revelation'.

Global trends and challenges: Christian faith, education and development, women and children, water and food, improved health, economic opportunities, environment and energy, societal complexities and ethical governance.

Bible translation as mission: The spiritual understanding gained from the vernacular scriptures encourages harmony within the emerging Christian communities. Through reading and understanding the translated Scripture, people are made aware of God and his desire to have a relationship with them. They can become equipped to do theology in their context and apply this to daily life.

The availability of vernacular scriptures has been the groundwork for effective cross-cultural mission as 'the complicated task of translating the Bible ... has sometimes been an outgrowth of mission activity [and] sometimes the entering wedge' (Smalley 1991:21). Participants in Bible translation understand that the Bible is about all of life and it speaks for itself and should be freed 'from its spiritual captivity and [be allowed] to engage and speak to the whole of human life' (Myers 1999:227).

Bible translation puts power into the hands of ordinary people, to apply God's word in their lives and in their culture. This makes the Bible radical for those who are poor and oppressed because it 'empowers the powerless and forces the powerful to recognise their own weakness before God' (Shaw 2000:125). The Bible also shows that 'no people group can be truly independent, but needs to recognize its interdependence with others, even as they express mutual dependence on God' (Shaw 2000:125).

\section{Transformation because of Christ}

9. 'Believe that transformation in a person comes through a relationship with Christ. There is no substitute for a living, growing faith'.

Global trends and challenges: Christian faith.

Bible translation as mission: A goal of Bible translation is for people to understand the Bible and come to a personal faith in God. The translators of the King James Version of the Bible stated (KJV Preface 1611; Ps 48):

$[T]$ o have the Scriptures in the mother tongue is not a quaint conceit lately taken up ... but hath been thought upon, and put in practice of old, even from the first times of the conversion of any nation; no doubt because it was esteemed most profitable to cause faith to grow in men's hearts ... and to make them to be able to say with the words of the Psalm, As we have heard, so we have seen. (p. 3; v. 8)

Kwame Bediako (2001) observes:

African Christianity today is inconceivable apart from the existence of the Bible in African indigenous languages ... Africans had the means to make their own responses to the Christian message, in terms of their own needs and according to their own categories of thought and meaning. (p. 3)

Bible translation in the context of the world's minority people groups ensures that 'the Bible empowers the powerless and forces the powerful to recognize their own weakness before 
God' (Shaw 2000:125). The spiritual understanding gained from the vernacular scriptures encourages harmony within the emerging Christian communities.

The action of Christians throughout church history demonstrates that Bible translation has made a significant difference to the acceptance of the gospel, the growth of the church and the discipling of people. The translatability of the Bible empowers people and societies to be better equipped through their vernaculars to deal with changes brought upon them by outside influences and adapt to their changing contexts.

Transformation in a community takes place when the Holy Spirit interacts with people about their relationship with the triune God, their mutual relationships within their community and their relationship with God's creation. These restorative outcomes are indicators of shalom.

\section{The role of churches in transformation}

10. 'Recognize churches as foundational for sustained and abundant transformation. To strengthen existing churches, or to plant new ones where none exist, forms a powerful community of transformed lives empowered by God with hope and kingdom values'.

Global trends and challenges: Christian faith, education and development, economic opportunities and women and children.

Bible translation as mission: Bible translators assume that the sacred text was never meant to be restricted to any one language and culture. They accept the principle that Jesus spoke Hebrew and Aramaic (and possibly Greek) but he did not restrict his teaching to these languages. Texts such as Matthew 28:18-20 and Revelation 5:7 and 7:9 provide the mandate that Jesus' words will be communicated through his followers to people of every language, nation and ethnic group. This complex responsibility is why Andrew Walls (1992:24) calls it 'the art of the impossible' and it is obviously not for the fainthearted. In order for the gospel to be effectively understood in any context, it has to be planted firmly in appropriate 'cultural soil'.

Bible translation is in support of the local churches where they have been established. They are the owners and primary participants of the Bible translation process. Through interacting with the translated scripture, people 'develop an awareness of God and understand their relationship to him' (Shaw 2000:125). They are also no longer dependent upon the outside the world and are equipped to do theology in their context and apply this to daily life.

Common to contexts where Bible translation is still needed is the matter of church services and worship held in a second language, such as a national language. However, as vernacular translation gets underway, it leads to changes as it gets used in sermons and teaching and worship songs. Research conducted in such communities notes how this empowers 'congregations to reflect on Biblical instruction, subsequently leading to changes in organizational structures and congregational relationships as Biblical principles [are] applied and contextualized for local and denominational church governance' (Reesor et al. 2009:10).

\section{Summary}

The final aspect for a framework has been developed using Voorhies' 10 principles for holistic transformational development. Integral with these are the 10 GTCs. Finally, the contribution of Bible translation to holistic mission is incorporated into this framework that is intended to assist the church, holistic mission practitioners and participants of the Bible translation movement. Taken together, they provide insights into what a vision for shalom could look like.

\section{Conclusion}

Through this research, a framework has been developed that assists the church by addressing these considerations:

1. There is a connection between the Old Testament vision for shalom and Bible translation: without the Bible in the world's languages, people who are linguistically marginalised are denied the whole counsel of God. Consequently, there is less likelihood of complete transformational development occurring. Shalom results in people's wholeness as they find their identity in Christ, discovered through the availability of the Bible.

2. There is relevance of the Old Testament vision of shalom to the 21st-century global challenges and trends: the vision is needed because it is part of the whole counsel of God that transcends human history. All of the global challenges and trends demonstrate this because all need shalom to touch them.

3. Bible translation fits into a framework of holistic mission: the commitment of making the Bible available in the languages of the world has aided holistic development. Bible translation focuses on the mind (theological, evangelistic and on discipling) with the physical and practical needs of the body and spirit being outcomes of the scriptures being integrated into people's daily lives with ethical standards. Bible translation has enabled the world's minority people groups to encounter holistic mission as they become stronger, empowered to understand their need of God and strengthened with esteem to make a difference in word, deed and sign.

\section{Acknowledgements Competing interests}

The author declares that he has no financial or personal relationships that may have inappropriately influenced him in writing this article.

\section{Author's contributions}

The author was solely responsible for this work. 


\section{Ethical consideration}

This article followed all ethical standards for a research without direct contact with human or animal subjects.

\section{Funding information}

This research received no specific grant from any funding agency in the public, commercial or not-for-profit sectors.

\section{Data availability statement}

Data sharing is not applicable to this article as no new data were created or analysed in this study.

\section{Disclaimer}

The views and opinions expressed in this article are those of the author and do not necessarily reflect the official policy or position of any affiliated agency of the author.

\section{References}

Aldred, R., 2003, 'Cross-cultural conversion', Unpublished paper presented to Urbana 2003, Urbana, IL.

Bediako, K., 2001, 'The role and significance of the translation of the Bible into African languages in the consolidation of the church and its expansion into unreached areas', Unpublished paper presented to Wycliffe Bible Translators International Africa Area Forum, Nairobi.

Bradshaw, B., 2000, 'Transformational development', in A.S. Moreau (ed.), Evangelical dictionary of world missions, p. 966, Baker Books, Grand Rapids, MI.

Burnett, D.G., 1986, The healing of the nations: The biblical basis of the mission of God, Paternoster Press, Carlisle.

Cantoni, G., 1997, 'Keeping minority languages alive: The school's responsibility', in Teaching indigenous languages, viewed 18 February 2015, from https://jan.ucc. nau.edu/ jar/TIL_1.html.

Dictionary.com, Peace, viewed 09 August 2019, from https://www.dictionary.com/ browse/peace.

Douglas, J.D. (ed.), 1975, Let the earth hear his voice: International Congress on World Evangelization, Lausanne, Switzerland, World Wide Publications, Minneapolis, MN.

Elson, B., 1987, Linguistic creed, viewed 18 February 2015, from https://www.01.sil. org/sil/linguistic_creed.htm.

Engelsviken, T., 2003, 'Missio dei: The understanding and misunderstanding of a theological concept in European churches and missiology', International Review of Mission 92(367), 481-497. https://doi.org/10.1111/j.1758-6631.2003.tb00424.x

Ethnologue, n.d., Kenye, viewed 18 February 2015, from https://www.ethnologue. com/language/lke.

First Fruits, 2009a, The early years, viewed 28 August 2019, from https://firstfruit.org/ about-us/.

First Fruits, 2009b, Global trend analysis, viewed 27 August 2019, from https:// sp2018djndwjg.wpengine.com/global-trends-analysis-part-1/; https://sp2018djndwjg. wpengine.com/global-trends-analysis-part-2/; and https://sp2018djndwjg.wpengine. com/global-trends-analysis-part-3/.

Foster, R.J., 2005, Freedom of simplicity, rev. edn., Kindle Edition, Zondervan, Grand Rapids, MI.

Goodrick, E.W. \& Kohlenberger, III, J.R., 1999, Zondervan NIV exhaustive concordance, 2nd edn., Zondervan, Grand Rapids, MI.

Harris, D.J., 1970, Shalom! The biblical concept of peace, Baker Book House, Grand Rapids, MI.

Harrison, D.K., 2010, 'Foreword', in M. Beerle-Moor \& V. Voinov (eds.), Language vitality through Bible translation, pp. vii-viii. Peter Lang, New York, NY.

Hesselgrave, D.J., 2016, 'Saving the future of evangelical missions', in R.C. Scheuermann \& E.L. Smither (eds.), Controversies in mission, Kindle edn., loc.5041-5456. William Carey Library, Pasadena, CA.

Hill, H., 2006, 'The vernacular treasure: A century of mother-tongue Bible translation' International Bulletin of Mission Research 30(2), 82-88. https://doi.org/10.1177/ 239693930603000208

Hunter, J.D., 2010, To change the world, Oxford University Press, Oxford.

Jenkins, P., 2006, The new faces of Christianity: Believing the Bible in the global south, Oxford University Press, New York, NY.

Kirk, A., 2006, Mission under scrutiny, Darton, Logman + Todd, London.
KJV Bible, 1611, Preface (edited for contemporary English), viewed 15 October 2019 from https://en.wikisource.org/wiki/Bible_(King_James)/Preface.

Konfe-Tiendrebeogo, B., Ngum Kimbung, J. \& Engeler, M., 2014, Impact assessment report ANTBA, CABTAL, OneBook: Transforming nations, OneBook, Calgary.

McIntosh, J.A., 2000, 'Missio dei', in A.S. Moreau (ed.), Evangelical dictionary of world mission, Baker Books, Grand Rapids, MI.

McLaren, B., 2007, Everything must change: Jesus, global crises, and a revolution of hope, Thomas Nelson, Nashville, TN.

Micah Global, n.d., Mission, viewed 28 September 2019, from https://www. micahnetwork.org/mission.

Millennium Project, 2009a, viewed 28 August 2019, from https://www.millenniumproject.org/about-us/.

Millennium Project, 2009b, 15 Global challenges, viewed 27 August 2019, from https://www.millennium-project.org/projects/challenges/.

Myers, B.L., 1999, Walking with the poor: Principles and practices of transformationa development, Orbis Books, Maryknoll, NY.

Neill, S., 1986, A history of Christian missions, Penguin Books, London.

Ngoma, A., 2013, 'A biblical framework for sustainable development in the reformed church in Zambia: The story of George compound in Lusaka', Doctoral dissertation, Faculty of Theology Department of Practical Theology \& Missiology, Stellenbosch University.

OneBook, 2014, Impact assessment report, OneBook, Calgary.

Ott, B., 2004, God's shalom project: An engaging look at the Bible's sweeping story, Good Books, Intercourse, PA.

Padilla, R.C., 2004, 'Holistic mission', in D. Claydon (ed.), Holistic mission occasional paper, no. 33, pp. 11-23, Lausanne Committee for World Evangelization, Orlando, FL.

Pitman, D.A., Habito, R.L.F. \& Muck, T.C., 1996, Ministry and theology in global perspective: Contemporary challenges for the church, Wm. B. Eerdmans perspective: Contemporary
Publishing, Grand Rapids, MI.

Reesor, A.D., Chandler, M. \& Gackenbach, P., 2009, 'Impact and outcome instrument development phase report', prepared for The Seed Company, Metadigm Group, Atlanta, GA.

Sanneh, L., 2002, Whose religion is Christianity?, Eerdmans, Grand Rapids, MI.

Starrenburg, S., 2019, 'Why does Bible translation matter?', Unpublished PowerPoint presentation, United Bible Societies, Fortitude Valley, QLD.

Shaw, R.D., 1988, Transculturation: The cultural factor in translation and other communication tasks, William Carey Library, Pasadena, CA.

Shaw, R.D., 2000, 'Bible translation', in A.S. Moreau (ed.), Evangelical dictionary of world missions, pp. 123-126, Baker Books, Grand Rapids, MI.

SIL International, n.d., viewed 18 February 2015, from https://www.sil.org/literacyeducation.

Silzer, P.J., 2000, 'Transformational', in A.S. Moreau (ed.), Evangelical dictionary of world missions, pp. 967-968, Baker Books, Grand Rapids, MI.

Smalley, W., 1991, Translation as mission: Bible translation in the modern missionary movement, Mercer University Press, Macon, GA.

Steward, J., 2000, 'Biblical holism', in A.S. Moreau (ed.), Evangelical dictionary of world missions, p. 448, Baker Books, Grand Rapids, MI.

Sultan, S., 2007, 'Reconciliation as mission', in Encounters mission Ezine, pp. 1-4, 16 February, Redcliffe College, Gloucester, viewed 10 February 2020, from https:// encountersmissionjournal.files.wordpress.com/2011/07/reconciliation as mission_16-1.pdf.

UNESCO, 2007, Advocacy kit for promoting multilingual education: Including the excluded, viewed 04 October 2019, from https://unesdoc.unesco.org/images/0015/ 001521/152198e.pdf.

Van Wynen, S., Crough, D. \& Franklin, K., 2019, 'Wycliffe Global Alliance foundational statements', Unpublished paper, Wycliffe Global Alliance, Singapore.

Voorhies, S.J., 1999, 'Transformational development: God at work changing people and their communities', in R.D. Winter \& S.C. Hawthorne (eds.), Perspectives on the world Christian movement, pp. 586-591, William Carey Library, Pasadena, CA.

Walls, A., 1992, 'The translation principle in Christian history', in P. Stine (ed.), Bible translation and the spread of the church: The last 200 years, pp. 24-27, E.J. Brill, New York, NY.

Wycliffe Global Alliance (WGA), 2018, Scripture and language statistics, viewed 27 August 2019, from https://www.wycliffe.net/en/statistics.

Wycliffe Global Alliance (WGA), 2019, 'Wycliffe Global Alliance Bible translation programs philosophy', Unpublished paper, Wycliffe Global Alliance, Singapore.

Winter, R.D., Steven, C. \& Hawthorne, S.C., 1999, Perspectives on the world Christian movement: A reader, 3rd edn., William Carey Library, Pasadena, CA.

Wolterstorff, N., 1983, Until justice and peace embrace, William B. Eerdmans, Grand Rapids, MI.

Woodford, B., 2007, Master plan: Biblical foundations for living churches, Eastwest College of Intercultural Studies, Taupiri.

Yoder, P.B., 1997, Shalom: The Bible's word for salvation, justice and peace, Wipf \& Stock, Eugene, OR

Young, C., 2011, 'Enablers and constraints of an effective and sustainable mothe tongue-based multilingual education policy in the Philippines', PhD thesis, School of Education, Bangor University, Bangor, UK. 